\title{
TERRITORIAL IDENTITY OF COUNTRYSIDE RESIDENTS IN THE SUBURBAN AREAS OF ŁÓDŹ, POLAND
}

\author{
MARCIN WójCIK \\ Department of Regional and Social Geography, University of Łódź, Poland \\ Manuscript received: October 20, 2012 \\ Revised version: April 23, 2013
}

Wójсік M., 2013. Territorial identity of countryside residents in the suburban areas of Łódź, Poland. Quaestiones Geographicae 32(2), Bogucki Wydawnictwo Naukowe, Poznań, pp. 69-79. 5 figs. DOI 10.2478/quageo-2013-0014, ISSN 0137-477X.

ABSTRACT. Social studies of suburban villages have important implications for modern human geography. To a large extent, they relate to a broader problem, which is a change in the value system of Polish society and the needs met in the countryside environment. It is worth considering how a society with specific needs changes the space of the contemporary suburban village. The knowledge of those processes is necessary to further develop spatial policies and local development of gminas (communes) in Poland, especially in the case of rapidly transforming villages in the vicinity of large cities. The primary objective of this paper is to identify differences in the territorial identity and social perception of rural space expressed by immigrant and local groups of long-term residents.

KEY WORDS: suburban areas, human ecology, Łódź Metropolitan Area

Marcin Wójcik, Department of Regional and Social Geography, University of Łódź, ul. Kopcińskiego 31, 90-142 Łódź, Poland; e-mail:marwoj@geo.uni.lodz.pl

\section{Introduction: social rural studies in human geography}

The socio-economic transformation in Poland in the 1990s has resulted in big changes in Polish rural areas. Those processes involved not only a transformation of their economic (functional) structure, but also a social transformation. Social change in rural areas is visible, among others, in the diversification of professional and income structure of the population, as well as in social needs and life styles (cf. Fedyszak-Radziejowska 2012, Wieruszewska 2012). Social and cultural changes have spatial implications. They are reflected in the ongoing complication of spatial arrangements of settlements, including rural architecture (cf. Wójcik 2006, Bański \& Wesołowska 2012). These changes are the most apparent within the areas of influence of big cities. Regardless of their scientific description (such as suburban areas or urban fringe), they are characterised by highly dynamic processes of social and economic change.

This article focuses primarily on local phenomena, and the presentation and interpretation of events is made from the perspective of social rural geography research. Social rural research in Polish human geography has never been a particularly popular topic of publica- 
tions. There are many reasons for that. One of the most important is the dependence of rural studies on the issues tackled by urban studies. Rural transformation is often interpreted from the point of view of the city, which translates into its incogitant adaptation to theories and concepts, assuming some universality of urban social and economic processes or their systemic superiority (e.g. the concepts of urbanisation and metropolitanisation). The conceptual dependence of researchers studying rural issues on those studying cities mainly means that a rural geographer or sociologist cannot omit urban theories and methodologies, as they determine the main trends in science. Hence, modern rural geography as a complex discipline (Pacione 1984, Bański 2002, Wójcik 2012) requires not only a vast social, economic and cultural knowledge (competence), but also a knowledge of current theoretical trends and the methodology of urban studies as a force propelling every social science.

The adoption of the 'rural' point of view in the study of suburban villages changes the research perspective, i.e. the observation and interpretation of social transformations in the countryside is made not from the point of view of the city creating migration traffic, but from that of quickly changing villages. This means that concepts of urbanisation (suburbanisation) are used less. The significance of endogenous structures and resources is much more pronounced (e.g. the concept of the local community).

The problem has been widely discussed in publications on the topic. Highly developed countries started looking at rural areas differently when their growing social and functional diversity became an interesting topic of scientific debates. Attempts at describing the changes observed in the countryside in the 1970s based on measurable features and the construction of 'indexes of rurality' did not answer fundamental questions concerning the nature of the processes (Cloke 1977). The rural post-productivism started showing in its growing significance as a constant or temporary place of residence, rest and recreation, as well as non-agricultural employment. This diversity started to generate social and spatial conflicts and, above all, raise questions about the cultural identity and basis for identification of the rural population.
At the beginning of the research, the social approach to the problem of rural development in geography involved the concept of an urbanised community. It assumed that local communities evolved from closed systems towards open social systems, and the factor responsible for this change was the diffusion of an urban lifestyle (urbanisation of rural areas). Its spread was associated either with the majority of the rural population being migrants from urban areas (especially in the vicinity of big centres), or with the influence of mass cultural models through the media and other forms of social communication (Pahl 1965, Lewis \& Maund 1976). In the face of declining birth rates, the migration was credited with changing social behaviour. Migrations related to the life cycle of the respective groups were also indicated as responsible for the erosion of traditional culture and the inclusion of rural communities into mass culture. Geographical studies of the 1960s and '70s sought to confirm the thesis that rural urbanisation differed spatially and depended on the distance from the closest city and its size (Lewis \& Maund 1976). The results suggested that local communities were cells of an urban-rural continuum, although those studies did not adhere to the strict rules of measurement and pointed to a variety of social behaviour patterns (the development of behavioural approaches in human geography).

Urbanised communities were characterised by certain universal spatial types of behaviour, which mainly included a close relationship with the cities around which they formed (daily migrations). Attention was also paid to considerable spatial mobility resulting from car ownership, special treatment of the place of residence as an important element of territorial identification, as well as consideration for environmental and functional (accessibility) aspects of one's environment (Connell 1974, Pacione 1980).

In the recent years, the research on the transformation in rural suburban areas involved analyses of urbanisation phases as part of the discussion of the life cycle of urban regions (Champion 2001, Geyer 2002). In the case of post-socialist countries, special attention was paid to the spontaneous nature of suburbanisation, which resulted primarily from the opportunities of free trade in land and the need of the more affluent groups 
of society to live in elite neighbourhoods on the outskirts of a city (cf. Leetmaa \& Tammaru 2007, Borén \& Gentile 2007). Studies also stressed the complex social nature of the urbanisation process resulting from different motivations of migration (cf. Tammaru 1999, Ouředníček 2007). Since those proposals were primarily formulated by specialists in urban processes, little attention was paid to changes and reactions of indigenous structures in suburban villages. This was pointed out by such researchers as, e.g., Phillips (2005), who highlighted the role of social change in indigenous communities subjected to the shock of an invasion of new residents and the relationships between the new and the long-time residents.

In conclusion, it should be noted that the concept of an urbanised community mainly emphasised the degree of similarity between the social structure of a given group to the social structure of a city and paid special attention to the spatial location of a community. Physical distance was considered a fundamental determinant of variability in a rural social community. The idea of an urbanised community also indicates certain social conditions (social needs) and economic ones (changes in the labour market), which determine the emergence of a social group on the outskirts of cities, quite wealthy and leading a characteristic life focused on consumption, as well as harmony and family values.

New research concepts in rural geography appeared with the interest in rural areas emerging in various social groups, which led in the 1980s and '90s to an increase in the number of rural residents. The main problem of geographical studies became to determine the motives behind this spatial behaviour and study the results of the growing diversity of rural areas. At the turn of the 1980s and '90s, various publications focused on the issue of a changing approach to rural studies, with emphasis placed on the social representation of the living environment. The proposed solutions moved away from defining rural areas through their functional aspect and were replaced by a normative approach, which translated into an appeal to social representations of rural areas or groups determining their change. These studies, particularly in Great Britain, evoked the stereotype of a rural idyll, i.e. the positive valuation of rural areas as a friendly, healthy environment close to humans (Halfacree 1993, 1995). The vision of a rural idyll is an expression of human longing for harmony resulting from contact with nature and social proximity. This type of geographical approach to rural problems was inspired by the work of sociologists and cultural anthropologists, but it did not copy the methodological solutions of the related sciences and re-interpreted the geographical concept of rural landscape and, above all, of locality (rurality). The adoption of this point of view showed that rural areas could assume many representations, depending not only on the type of social groups living there, but also on the cultural context of a region or state (Cloke et al. 1998). The rural idyll was a response to the ethnic, racial and class differences in large European cities, which were hard to assess. The idealisation of rural areas and the escape into locality reflects a longing for simplicity, clarity of the rural landscape and social environment, as opposed to the complexity of urban processes and the homogenisation brought about by globalisation.

The expansion of interest of human geography and the methodological diversification of the discipline, especially its 'cultural turn', also influenced the nature of rural studies. It was pointed out that the idyllic representation of the countryside was just one of many possible representations and perspectives in rural studies (Sibley 1995, Cloke \& Little 1997). In the concept of other rural, the interest of rural geography is directed at the problem of marginalisation and exclusion. These studies are opposed to the generalisation of local communities and the one-sided creation of a rural environment associated with the middle class. This is an approach taken by Philo (1992), arguing that rural geography has forgotten about other images of the countryside, the excluded and the marginalised.

The problem of suburban villages is thus interesting in numerous ways. Both the process of colonisation (appropriation) of new terrain by urban development and the reaction of indigenous people to this process are interesting. A scientific approach to such processes is also interesting and can be analysed not only from the point of view of certain theoretical and methodological approaches (positivist, radical, cultural), but also of the specificity of urban and rural geography. 
In this article, emphasis is placed on the tradition of rural studies.

\section{Concepts of studies of suburban areas in polish human geography}

For decades the transformation of suburban areas of large cities has been very popular with social scientists (e.g. those involved in human geography, sociology and regional economics). In Polish human geography, special attention is paid to the development of spatial differences in such areas, primarily in terms of functionality. It is emphasised that the concept of a suburban area has been transferred to geography from urban planning (cf. e.g. Straszewicz 1985). Those studies primarily dealt with changes in land use. On this basis, plans for the development of suburban villages were often created in the period of intense urbanisation of city fringes. Like sociological studies, geographical research conducted in the 1960s and '70s focused on the formation of labour-force settlement and its role in creating functional links between the city and its suburban areas (cf. Dobrowolska 1964, Golachowski \& Goldzamt 1971).

A detailed theoretical interpretation was presented in the mid-1980s. Dziewoński (1987: 58) believed that suburban villages were a set of systems of a certain type. Those villages, together with the city itself, formed a larger, overarching system (an urban area). Liszewski (1987) pointed out that the suburban areas existed as a result of the activity of two forces working in opposite directions: concentration (agglomeration) and deconcentration (diffusion). Therefore, suburban areas were considered rather unstable in terms of their morphological, functional and social aspects. An in-depth theoretical study of suburban settlements within the functional mainstream was undertaken by Maik (1985). The author attempted to define the concept of suburban areas in functional terms on the basis of a systemic analysis. Suburban areas perform tasks which for some reason cannot be performed in the city. Suburban villages change with the structural transformations of the city.

Most works in the 1970s and ' 80 s tried to prove that the study of urbanisation of subur- ban areas of large cities was allochthonous in origin, i.e. modernisation was mostly initiated by immigrants from other areas, forced to live in suburban zones of large cities, especially near railway lines that provided communication with urban centres. Geographers noted that areas of commuting intensity were not concentric, but took the form of belts called settlement belts (cf. Rakowski 1975, Jakóbczyk-Gryszkiewicz et al. 2010, Jędrzejczyk 1992).

The interpretation of urbanisation as a universal socio-economic process of transformation including rural areas caused protests among scholars dealing with rural development problems from the perspective of this living environment. A critical assessment of the concept of urbanisation formulated mainly in the framework of urban geography appeared in the works by Golachowski (semi-urbanisation, 1966) and Rakowski (organic urbanisation, 1975). Geographical publications included fewer views from scholars who approached this issue with much more reflection stemming from their research practice based on a different set of methods (sociological and anthropological). Of particular importance were the opinions formed by the research team of Dobrowolska. An attempt at scientific polemics was made by Prochownik (1975), who asked: "Rural urbanisation or de-ruralisation?" The essence of this way of thinking was dividing the processes and effects of changes taking place in the countryside into ones related to urbanisation in the strict sense and those caused by other circumstances, such as the modernisation of agriculture. De-ruralisation was thus a broader concept defining a number of phenomena that are signs of extinction of the traditional village. Urbanisation was associated with the direct influence of the city, especially in the realm of its physical expansion. The concept of de-ruralisation includes all transformations related to the modernisation of the countryside. It may also describe changes that lead to a total disappearance of the countryside.

The concept of suburban areas as a specific settlement system was formulated almost 30 years ago. It relied primarily on the concept of function, which was interpreted in terms of economic activity. In modern theoretical concepts, the economic understanding of function has been 
expanded to include social aspects. Social interpretation is mainly aimed at identifying the goals and motives of human actions (a behavioural approach). The geographical research on suburban areas (and on settlement systems) conducted since the early 1990s emphasises the need to link the functional and social interpretation of settlements, i.e.:

- the material basis: the theoretical base derives from the functional concept of the settlement network; and

- the local community: the theoretical base derives from the concept of social bonds (Maik 1993).

In the case of a suburban village, the concept of ecological areas, where the ultimate goal of research is to determine the relationship between the society and the territory, assumes a new meaning. The increased interest of geographers in social problems stems, on the one hand, from the general theoretical and methodological trends in social sciences associated with a new generation of explanation models, predominantly structuralist ones (Maik 1992). On the other hand, this evolution is dictated by the nature of the processes shaping the space of a village, which rely primarily on the transition from productivism to post-productivism and the application of (qualitative) research methods by which these phenomena can be described (cf. Wójcik 2008, 2012, Mantey 2011).

In social geography, the key concept in the study of human ecology is the social space. According to Maik and Stachowski (1995: 9), the concept of social space becomes real in the form of a territory (area) which a given local community uses and shapes, with which it integrates and identifies. Territorial identity, or a certain territorial affiliation, is an important component of local identity. Szczepański (2005: 127-129) identifies a set of values defined as "a local symbolic universe" as crucial for considerations focusing on local issues. This set includes social and territorial bonds, a sense of separateness in relation to other communities, forms of political and economic activity, historical consciousness and awareness of historical and cultural heritage, as well as a material form of places. The symbolic universe defies rigid divisions into specific sciences and their research domains. This universe is a framework for local studies, whose main objective is to determine the type, level and nature of integration into the local environment.

The concept of social ecology has a long tradition, both in geographical and sociological studies (cf. e.g. Węcławowicz 2007, Jałowiecki \& Szczepański 2009). In geographical research on rural settlements, studies of socio-spatial differences did not attract much interest. This lack of interest in the social ecology of rural areas was primarily the result of the homogeneity of rural communities (Pióro 1982: 42). From a geographical point of view, the small spatial extent of settlements was an important obstacle which made it impossible to present spatial diversity of ecological areas by dominant-pattern research. Economic geography, focused on the factors and effects of rural production, failed to discuss the issue of socio-spatial differences in any broader scope, leaving it to sociological studies (cf. e.g. Piotrowski 1982). Pióro (1982: 49) talks about 'ecological nests', i.e. historically formed spatial complexes of diversified spatial material (physiognomic, standards of housing) and social characteristics. One feature of such a 'nest' is the homogeneity of physical and spatial features of settlements, as well as of the social and economic features of their populations.

The meeting between incoming and resident social groups is not only a confrontation in the spatial sense (fixed and new living environments) but, above all, a cultural clash. In small social and territorial environments such as villages, social stratification is particularly readily visible, and spatial proximity allows mutual observation and social interactions different from those in the city. The cultural clash results from a difference in value systems and perceptions of countryside benefits. The main objective of this paper is to identify differences in territorial identity and the social perception of suburban village space between newcomers (immigrants) and long-term residents. ${ }^{1}$

\footnotetext{
1 The paper presents selected preliminary results of a social research conducted under the project "The socio-spatial transformation of villages of the Łódź Metropolitan Area" funded by the Polish National Science Centre (implementation period 2011-2013).
} 


\section{Housing policy of rural communes in the suburban areas of Łódź}

The housing policy of communes located in the suburban areas of large cities, including the Łódź Urban Agglomeration, is created largely under the settlement pressure of people of high economic status seeking better living conditions (cf. Wójcik 2008, Jakóbczyk-Gryszkiewicz et al. 2010). Since the mid-1990s, suburban villages have seen increased trade in land intended for the residential function. The effect has been a rising price of land for development, which also boosts the interest of the local population in the transformation of agricultural land into investment sites (mainly residential). Housing policy, as one of the elements of the spatial policy of a commune, has become crucial in determining directions of further development of suburban areas.

According to the research on directions in the spatial policies of communes of the Eódź Urban Agglomeration, an essential element of crystallisation of the settlement network is the residential and recreational functions (Milewska-Osiecka 2010). Attractive natural areas with good access to the city centre are of particular importance for the delimitation of new residential areas (cf. Milewska-Osiecka 2010, Wójcik 2008). The most common way to create a new housing function is to complement the existing village sites along the main and local roads. On analysis of the planning documents of the Łódź Urban Agglomeration communes, Milewska-Osiecka (2010) distinguished several types of policies developed to create a housing function. In the case of rural areas in the suburban zone, the author identified two main types, namely:

- communes with an expansionary policy, oriented at the development and dominance of the residential function; and

- communes with a complementary housing policy, determined by the development of other functions.

Regardless of the level of activity of communes in developing plans of new residential areas, a characteristic feature of the changes is the communes relying on an external stimulus for their development, in this case residential investment. Planning documents, however, rarely consider social effects of such a policy. Spatial policy leads to growing disparities in the social structure, hence the formation of spatial division lines in the villages, which were characterised by significant homogenisation in terms of the professional status and wealth of their populations until the beginning of the transition period (cf. Wójcik 2008). Social diversification, strongly associated with the change of the functional, spatial and physiognomic structures of rural settlements, forces the populations of newcomers and longtime residents not only to lead different lifestyles, but also to experience the village space differently, and thus creates different types of a symbolic relationship with the environment they live in.

\section{Selection of villages and respondents for fieldwork}

The social fieldwork was conducted in 17 villages of rural communes adjacent to the core areas of the Łódź Urban Agglomeration (Łódź, Zgierz, Pabianice). The selection of the villages was guided by their specific spatial structure, i.e. the settlements chosen had undergone intensive development since the 1990s, and new built-up lots made up $25 \%$ to $50 \%$ of all land intended for the housing function. This method of selecting villages created an opportunity to interview new and long-time rural residents who observed and contacted one another for a long time (10-15 years). ${ }^{2}$

In the studied villages, 301 questionnaire interviews were conducted, including 114 (38\%) with new residents and 187 (64\%) with long-time ('old') residents. In each village, there were an average of 15 to 18 interviews conducted with the representatives of both social groups. Men slightly dominated (54\%) in the structure of the respondents. Generally, the biggest age groups were those of 41-60 years (42\%) and 26-40 years $(24 \%)$. The reason for this overrepresentation was the assumption of the survey. Interviews were carried out primarily with the creators of the residential function (those most involved in the de-

\footnotetext{
2 Questionnaire interviews were conducted in the following communes: Stryków, Nowosolna, Rzgów, Pabianice, Zgierz, Aleksanderów Łódzki, Lutomiersk, and Dobron.
} 


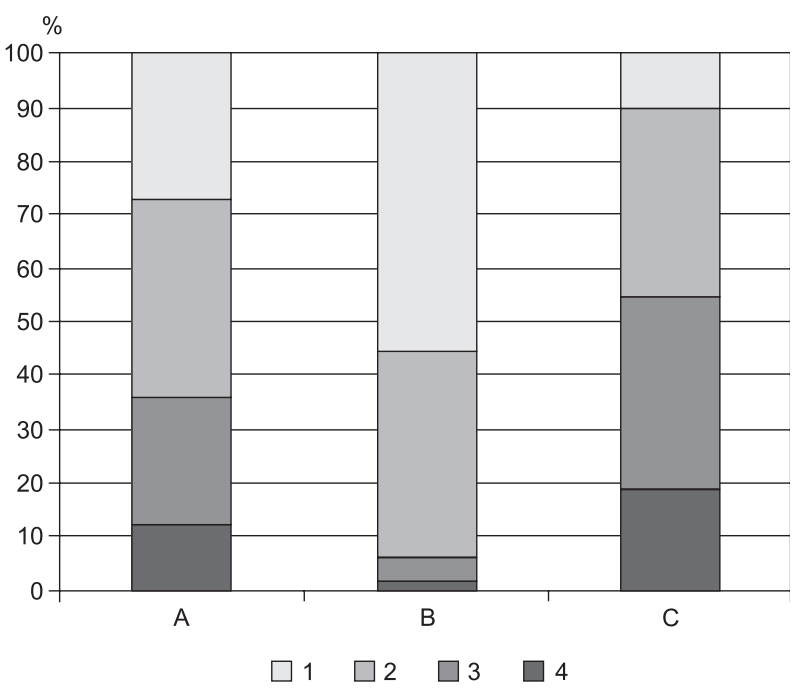

Fig. 1. Respondents by education level. A. total respondents, B. new inhabitants, C. long-time residents. Education: 1. higher, 2. secondary, 3. vocational, 4. primary Source: author's compilation.

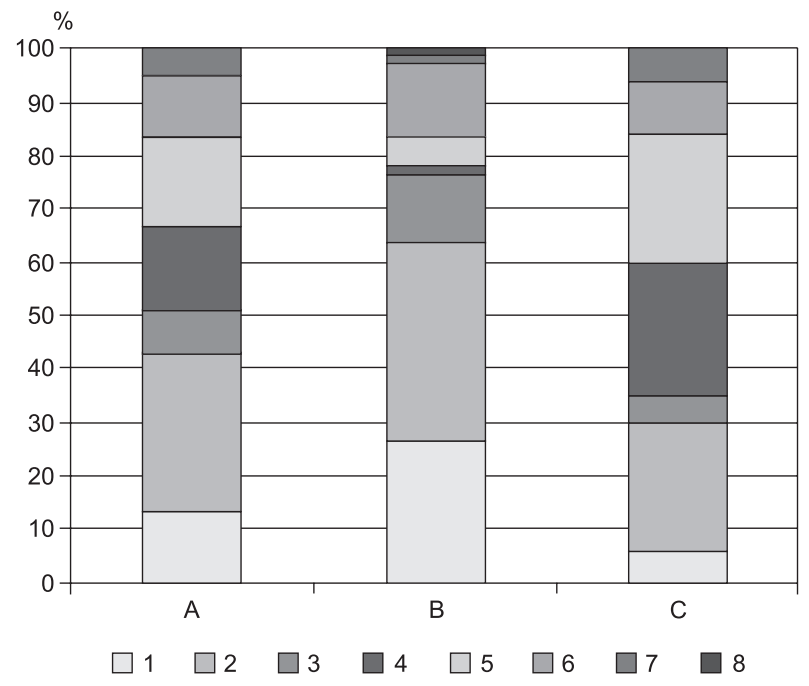

Fig. 2. Respondents by type of economic activity. A. total respondents, B. new inhabitants, C. long-time residents. Professional activity: 1. employed in public sector, 2. employed in private sector, 3. entrepreneur, 4. farmer, 5 . retired, pensioner, 6 . pupil, student, 7. unemployed, 8. not found Source: author's compilation.

from 1 (very low) to 5 (very high). The highest level of identification was found in the case of Poland and the place of residence (Fig. 3), which corresponds to two major categories of social identity of Poles, i.e. identification with their ideological homeland (the state) and 'the little homeland', i.e. their closest area (familiar space).

In the case of new residents, the level of identification with all of the above-mentioned areas was the most balanced. This was due to their higher daily mobility and various territorial identities in the various stages of life (living in

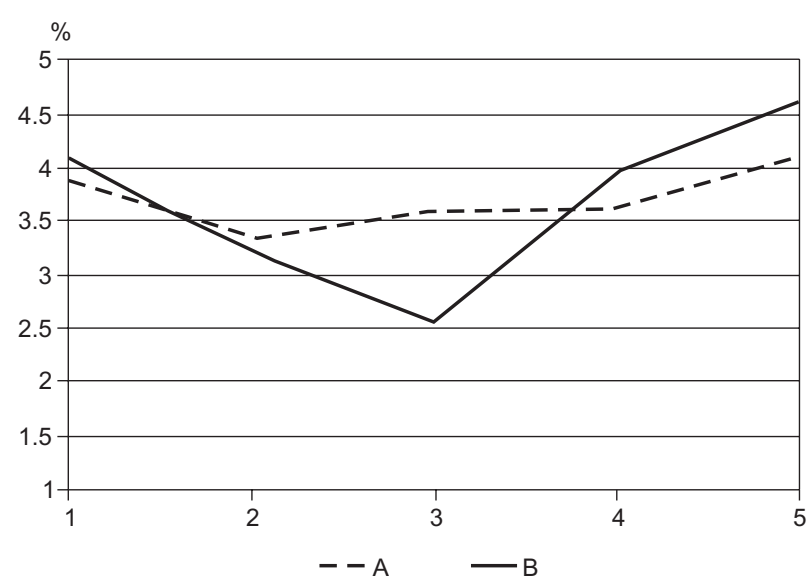

Fig. 3. Level of identification of new and long-time residents with selected areas.

A. new residents, $B$. long-time residents

1. Poland, 2. Łódź region, 3. Łódź, 4. commune, 5. village Source: author's compilation. eas, such as Poland, the Łódź region, Łódź, the commune, and their own village, using a scale 
a metropolitan centre, then on its outskirts). The territorial identification of new residents tended to be shaped by their present place of residence (home) rather than place of work or former residence, even if they lived longer in the previous place than in the current suburban village. Both groups, however, showed a low level of identification with the region. In the case of the Łódź region (Central Poland), regionalism is still in the process of formation. The history of the development of Łódź and its administrative identity, which was assigned to it as late as 1918, as well as the evolution of administrative divisions of the country, including the one in the years 1975-1998, destructive to regional identity, have not been conducive to building connections with the region. In contrast to the new residents, people living in villages for a long time and in most cases representing a rural continuity of agrarian tradition, showed higher levels of identification not only with their place of residence, but also with the commune area. They operated in local systems more often, satisfying their social needs in the centres of social and economic life (e.g. in small towns) on the outskirts of the urban agglomeration.

The differences in the level of territorial identification between the two groups were confirmed by the distribution of responses con-

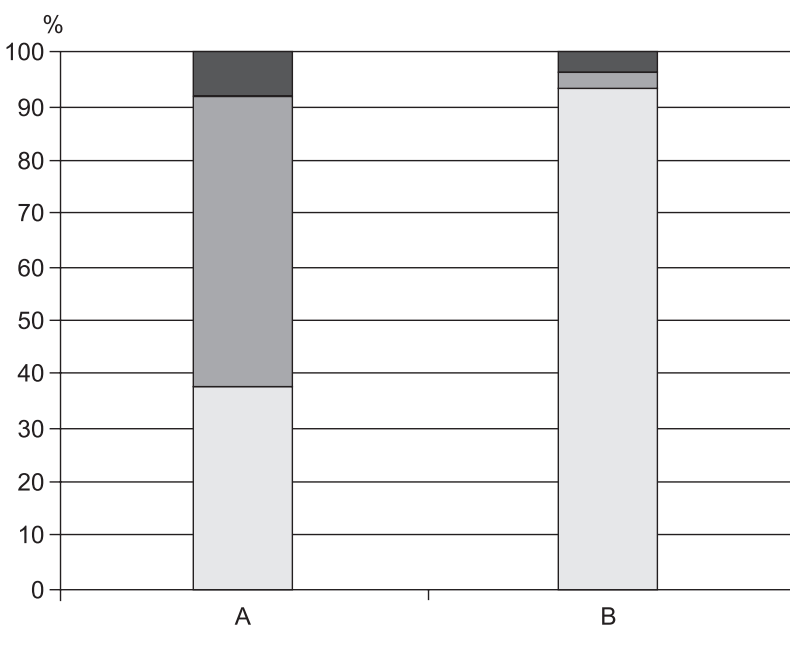

$\square 1 \square 2 \square 3$

Fig. 4. Relation of respondents to their place of residence. A. new residents, $\mathrm{B}$. long-time residents.

1. I feel connected with the place and with the local community; 2. I feel connected with the place, but people who live here are indifferent to me; 3 . both the place and the people living here are indifferent to me.

Source: author's compilation. cerning their place of residence (rural areas). Over $90 \%$ of long-time residents answered that they felt a bond with the village and the local community (Fig. 4). The newcomers, however, more often reported a commitment to the village (place of residence) and indifference towards the local community. This shows that immigrants are largely responsible for changing local communities into territorial communities by using the same space, but without any forms of local social integration.

In both groups the respondents were also asked to express an opinion on maintaining relations between new and long-time residents. Opinions varied within the groups. Approximately $50 \%$ of the respondents in each group believed that maintaining mutual contacts was important or very important. More enthusiasm (although the advantage is not big) towards the other group was shown by new residents, but the responses indicating little interest in maintaining contacts with the long-time residents were also quite numerous. A positive attitude towards social integration of all inhabitants is a personal matter and is mainly due to experiences with neighbours.

The final elements subjected to evaluation by the respondents were positive and negative consequences of the influx of new residents into the

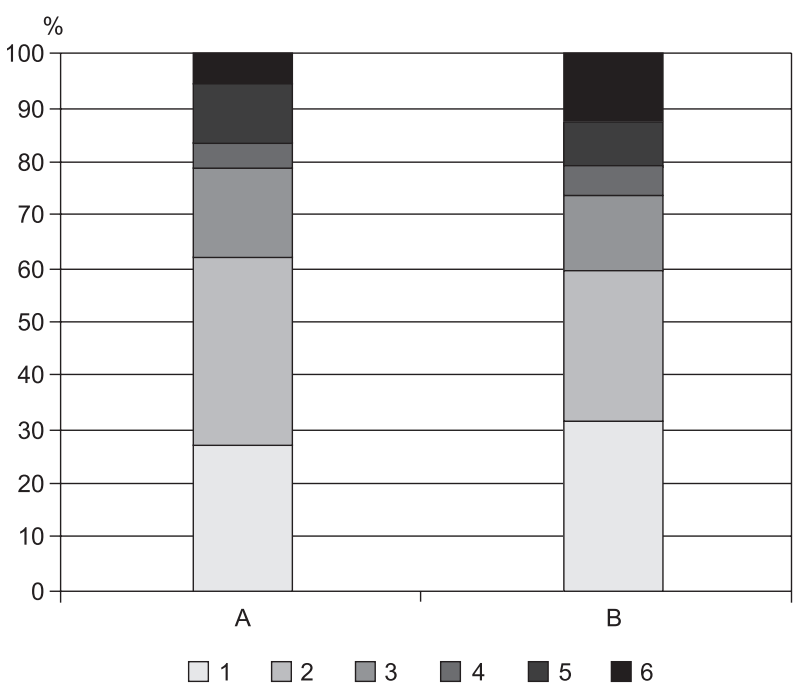

Fig. 5. Positive consequences of the influx of new residents A. new residents, B. long-time residents

1. population growth, 2 . spatial development, 3 . aesthetic value, 4 . no positive effects, 5 . other, 6 . no response Source: author's compilation 
village. In this case, the responses of both groups did not differ much (Fig. 5). Among the positive aspects of this process, those mentioned most often were population growth and the growth of the village. In the face of depopulation of a substantial part of rural areas of the country and regions, population growth and infrastructural growth of villages in suburban areas is a factor stimulating local entrepreneurship and social initiatives. Residents emphasised the aesthetic improvement of their villages, which was mainly due to the introduction of new architectural forms, together with accompanying gardens. The respondents assessed favourably the increased diversity of development, rarely noting the growing chaos in management.

Among negative consequences, the respondents most frequently cited the expansion of construction and management of open spaces. Many residents rated low the traffic congestion which is a derivative of population growth caused by those having a different lifestyle and mainly working in the city. They also noted that new forms of housing entailed spatial separation as expressed by more numerous fences. Fencing out, like the cause of this phenomenon, i.e. an increasing socio-professional diversity, was equally poorly judged by both groups of respondents. The long-time residents mentioned many negative consequences that were difficult to classify. They included border disputes, animosities connected with obtaining profits from the sale of land, or inappropriate behaviour of new residents towards the local community (such as boasting and demonstrating their wealth and higher social status).

\section{Discussion}

The study illustrates selected social consequences of spatial policy regarding housing in rural communes in the suburban area of a big city. The results show that this process generally leads to social and spatial diversification. Unlike macro-scale studies, both Polish (cf. Jakóbczyk-Gryszkiewicz et al. 2010) and foreign (such as Leetmaa \& Tammaru 2007), micro-scale studies have shown that differences are even greater and concern neighbouring areas. Model approaches generalise this process and do not reflect the real transformations stemming from cultural differences (contrasts). The results confirm the findings of other works, especially in sociology and anthropology (cf. Kajdanek 2012, Mantey 2011) concerning growing social disintegration, mutual distrust of human groups, and a clash between expectations (search for ideal living conditions) and the reality of the urbanised countryside, especially lack of satisfaction with one's neighbourhood. As a result of the influx of new residents to suburban villages, long-time communities of agrarian origin evolve towards social disintegration. Villagers become users of the same area (village) rather than social communities. The gradual marginalisation of groups of long-time residents advances not only due to changes in the ownership of land (land sale), but also as a result of cultural pressure. The different ways of life are manifested in different behaviour patterns and levels of territorial identity. New residents of a village perceive space primarily in terms of functional utility (convenience of residence), while long-time residents attach sentimental value to it, due to historical continuity.

The problem of the formation of the specificity of social environment in the suburban countryside should also be looked at more broadly, from a more abstract and relative point of view. This is due to the contemporary nature of the settlement network, interpreted in terms of a continuum. In the case of rural settlements or rural settlement systems, discussing them in terms of their daily activities requires considering their socio-cultural characteristics. In such a case, special attention is paid to social and spatial behaviour patterns stemming from the historical continuity of certain individual characteristics of functioning within a local structure. The functional concepts describing the diversity of settlements within the social and professional structures evolve towards the perception of social needs and the resulting spatial behaviour. From a geographical point of view, the integration of functional concepts (a settlement network) with social concepts (social space) relies heavily on the concept of 'nodality' of activities, which was called the time-space regionalisation of human behaviour by sociologist A. Giddens, fascinated with Hägerstrand's 'time geography'. Nodal regions are therefore under- 
stood not only in terms of the existence of sites (nodes) of concentration of flows ('streams') of goods and people, but also as certain territories where the 'paths of life' (routes of daily activities, biographies) meet social structures (cf. Thrift 1983, Kaczmarek 2005). Like cities, villages are 'arenas' of social processes (cf. Lisowski 1998) where individuals (people) meet not only social, but also natural structures. This is the fundamental difference in the development and interpretation of the specificity of the features of rural life in the circumstances of diminishing significance of economic (mainly agricultural) functions and the development of residential and other non-economic functions (the rise of the post-productivist countryside).

\section{References}

BAŃSKI J., 2002. Geografia wsi - nową dyscypliną badawczą polskiej geografii (Rural geography: A new research discipline in Polish geography). Przeglad Geograficzny, 74(3): 367-379.

BAŃSKI J. \& WesOŁOWSKA M., 2012. Architectural transformations of residential buildings in rural areas of the Lublin region. Architectoni.ca, 2(1): 174-186.

Borén T. \& Gentile M., 2007. Metropolitan processes in post-communist states. An introduction. Geografiska Annaler, Series B, Human Geography, 89(2): 95-110.

CHAmpion T., 2001. Urbanization, suburbanization, counterurbanization and reurbanization. In: Paddison R. (ed.), Handbook of urban studies. Sage, London: 143-161.

CloKe P., 1977. An index of rurality for England and Wales. Regional Studies, 11: 31-46.

Cloke P., Goodwin M. \& Milbourne P., 1998. Inside looking out, outside looking in. Different experiences of cultural competence in rural lifestyles. In: Boyle P. \& Halfacree K. (eds), Migrations into rural areas. Theories and issues. J. Wiley and Sons, Chichester: 135-150.

CloKe P. \& LitTle J. (eds), 1997. Contested countryside culture. Routledge, London.

ConNell J., 1974. The metropolitan village. In: Johnson J.H. (ed.), Suburban growth. Wiley, London.

DobrowolsKa M., 1964. Strefa podmiejska (Suburban zone). Rocznik Naukowo-Dydaktyczny WSP w Krakowie, 22: 101164.

DZIEWOŃSKI K., 1987. Strefa podmiejska - próba ujęcia teoretycznego (Suburban zone: An attempt at a theoretical approach). Przegląd Geograficzny, 59(1-2): 55-63.

FedyszAK-RADZIEJOWSKA B., 2012. Społeczności wiejskie: tożsamość, kapitał społeczny, wspólnotowe identyfikacje (Rural communities: Identity, social capital, community identifications). In: Rosner A. (ed.), Społeczne i kulturowe zagadnienia przemian na wsi polskiej. Instytut Rozwoju Wsi i Rolnictwa, Warszawa.

GEYER H.S. (ed.), 2002. International handbook of urban systems: Studies of urbanization and migration in advanced and developing countries. E. Elgar, Cheltenham.
GolachowsKi S., 1966. Urbanizacja wsi w województwie opolskim (Rural urbanisation in Opole region). In: Problemy ewolucji układów osadniczych na tle procesów urbanizacyjnych w Polsce. PWN, Warszawa: 45-66.

Golachowski S. \& Goldzamt E. (ed.), 1971. Problemy osadnictwa robotniczego na wsi (Problems of worker settlements in rural areas). Instytut Podstawowych Problemów Planowania Przestrzennego Politechniki Warszawskiej, Państwowe Wydawnictwo Naukowe, Warszawa.

HALFACREE K., 1993. Locality and social representation: Space, discourse, and alternative definitions of the rural. Journal of Rural Studies, 9: 23-37.

HALFACREE K., 1995. Talking about rurality: Social representations of the rural as expressed by residents of six English parishes. Journal of Rural Studies, 11(1): 1-20.

JaKóbczyK-GryszKieWicz J., MarcińczaK S. \& SiejkowsKa A., 2010. Dynamika i skutki procesów urbanizacji w regionach miejskich po 1990 roku na przykładzie regionu miejskiego Łodzi (Dynamics and effects of urbanisation in urban areas after 1990 on the example of the city of Łódź). Wydawnictwo Uniwersytetu Łódzkiego, Łódź.

JAŁOWIECKI B. \& SZCZEPAŃSKI M.S., 2009. Miasto i przestrzeń $w$ perspektywie socjologicznej (City and space in a sociological perspective). Wydawnictwo Naukowe Scholar, Warszawa.

JęDRZEjCZYK D., 1992. Procesy osadnicze w strefie podmiejskiej Warszawy (Settlement processes in the suburban areas of Warsaw). Prace Geograficzne, 13: 21-38.

KaczmareK J., 2005. Podejście geobiograficzne w geografii społecznej (Geo-biographical approach in social geography). Wydawnictwo Uniwersytetu Łódzkiego, Łódź.

KAJDANEK K., 2012. Suburbanizacja po polsku (Suburbanisation 'Polish style'). Nomos, Kraków.

LEETMAA K. \& TAMMARU T., 2007. Suburbanization in countries in transition: destinations of suburbanizers in the Tallin Metropolitan Area. Geografiska Annaler, B, 89(2): 127-146.

Lewis G. \& MAUnd D.J., 1976. The urbanisation of the countryside: a framework for analysis. Geografiska Annaler, B, 58: 17-27.

Lisowski A., 1998. Postmodernistyczna dekonstrukcja geografii miast (Postmodern deconstruction of urban geography). In: Kaczmarek J. (ed.), Metodologia geografii osadnictwa na przełomie wieków. X Konwersatorium Wiedzy o Mieście, Katedra Geografii Miast i Turyzmu, ŁTN, Łódź: 31-38.

LisZEWSKI S., 1987. Strefa podmiejska jako przedmiot badań geograficznych. Próba syntezy (Suburban zone as an object of geographical research. Attempt at a synthesis). Przegląd Geograficzny, 59(1-2): 65-79.

MAIK W., 1985. Charakterystyka strefy podmiejskiej w kategoriach funkcjonalnych. Próba rekonstrukcji modelu pojęciowego i metody badawczej (Characteristics of the suburban zone in functional terms. Reconstruction of the conceptual model and research method). In: Straszewicz L. (ed.), Pojęcia i metody badań strefy podmiejskiej. Acta Universitatis Lodziensis, Folia Geographica, 5: 41-60.

MAIK W., 1992. Problematyka rozwoju polskiej geografii społeczno-ekonomicznej w świetle paradygmatycznych modeli pojęciowych (Problems of development of Polish socio-economic geography in the light of paradigmatic conceptual models). Przeglad Geograficzny, 44(3-4): 231246.

MAIK W., 1993. Koncepcja lokalnych systemów osadniczych. Założenia i perspektywy badawcze (Conception of local settlement systems. Assumptions and research perspec- 
tives). In: Maik W. (ed.), Problematyka lokalnych systemów osadniczych. Uniwersytet Mikołaja Kopernika, Torun: 19-28.

Maik W. \& Stachowski J., 1995. Preteoretyczne modele pojęciowe $\mathrm{w}$ geografii społecznej i ich rola $\mathrm{w}$ budowie teorii i wyjaśnianiu zjawisk społeczno-przestrzennych (Pre-theoretical conceptual models in social geography and their role in the construction of theories and explanation of socio-spatial phenomena). Acta Universitatis Lodziensis, Folia Geographica, 19: 5-20.

MANTEY D., 2011. Żywiołowość lokalizacji osiedli mieszkaniowych na trenach wiejskich obszaru metropolitalnego Warszawy (Spontaneity of the location of housing estates in the rural areas of the metropolitan area of Warsaw). Uniwersytet Warszawski, Warszawa.

MilewsKa-OsiecKa K., 2010. Nowe budownictwo mieszkaniowe aglomeracji tódzkiej (New housing construction in the Łódź Agglomeration). Wydawnictwo Uniwersytetu Łódzkiego, Łódź.

OUŘEDNÍČEK M., 2007. Differential suburban development in the Prague urban region. Geografiska Annaler, Series B, Human Geography, 89(2): 111-126.

Pacione M., 1980. Differential quality of life in a metropolitan village. Transactions of the Institute of British Geographers, 5: 185-206.

PACione M., 1984. Rural geography. Harper and Row, London.

PAHL R., 1965. Urbs in Rure. Geographical Paper, 2. London School of Economics, London.

PHILIPS M., 2005. Differential productions of rural gentrification: Illustrations from North and South Norfolk. Geoforum, 36: 477-494.

Philo C., 1992. Neglected rural geographies: A review. Journal of Rural Studies, 8: 193-207.

PIOTROWSKI W., 1982. Struktury społeczno-przestrzenne gmin (Socio-spatial structures of communes). In: Pióro Z. (ed.), Przestrzeń i społeczeństwo. Wydawnictwo Książka i Wiedza, Warszawa.

Pióro Z. (ed.), 1982. Przestrzeń i społeczeństwo. Z badań ekologii czynnikowej (Space and society. Factorial ecology studies). Wydawnictwo Książka i Wiedza, Warszawa.

ProchownIK A., 1975. Urbanizacja wsi czy deruralizacja? (Urbanisation of the countryside or deruralization?). Czasopismo Geograficzne, 46(4): 399-405.

Próba delimitacji obszaru metropolitalnego Łodzi na podstawie ruchu wędrówkowego ludności w latach 1989-2007 (An attempt at delimitation of the metropolitan area of Łódź based on migration movement in the years 1989-2007). Collective work, 2008. Urząd Statystyczny w Łodzi, Łódź.
Rakowski W., 1975. Procesy urbanizacji wsi. Na przyktadzie województwa warszawskiego (Urbanisation of rural areas. The case of the Mazovia region). Studia Komitetu Przestrzennego Zagospodarowania Kraju PAN, 50. Warszawa.

SIBLEY D., 1995. Geographies of exclusion: Society and difference in the West. Routledge, London-New York.

Straszewicz L., 1985. Strefa podmiejska. Pojęcia i definicje (Suburban zone. Concepts and definitions). In: Straszewicz L. (ed.), Pojęcia i metody badań strefy podmiejskiej. Acta Universitatis Lodziensis, Folia Geographica, 5: 7-16.

SzcZEPAŃsKi M.S., 2005. Społeczności lokalne i regionalne a ład kontynentalny i globalny (Local and regional communities vs continental and global order). In: Wesołowski W. (ed.), Kręgi integracji i rodzaje tożsamości. Polska, Europa, Świat. Scholar, Warszawa: 121-140.

TAMmaru T., 1999. Differential urbanisation and primate city growth in soviet and post-soviet Estonia. Tijdschrift voor economische en sociale geografie, 91(1): 20-30.

THRIFT N., 1983. On the determination of social action in space and time. Environment and Planning, Series D, Society and Space, 1: 23-57.

WęCEAWOWICZ G., 2007. Geografia społeczna miast. Zróżnicowania społeczno-przestrzenne (Social geography of cities. Socio-spatial differences). Wydawnictwo Naukowe PWN, Warszawa.

WiERUSZEWSKA M., 2012. Lokalne, globalne, ponowoczesne wymiary kultury wsi (Local, global, postmodern dimensions of rural culture). In: Rosner A. (ed.), Spoteczne $i$ kulturowe zagadnienia przemian na wsi polskiej. Instytut Rozwoju Wsi i Rolnictwa, Warszawa.

WójcıK M., 2006. Przemiany siedlisk wsi pod wpływem urbanizacji we wschodnim paśmie aglomeracji łódzkiej (Changes in network of rural settlements under the influence of urbanisation process in the eastern belt of the Łódź urban agglomeration). Acta Universitatis Lodziensis, Folia Geographica Socio-Oeconomica, 7: 201-213.

Wóscik M., 2008. Przemiany społeczno-gospodarcze wsi w okresie transformacji ustrojowej (Socio-economic changes in rural areas during the systemic transformation). Wydawnictwo Uniwersytetu Łódzkiego, Łódź.

WójciK M., 2012. Geografia wsi w Polsce. Studium zmiany podstaw teoretyczno-metodologicznych (Rural geography in Poland: A study of changes in the theoretical and methodological foundations). Wydawnictwo Uniwersytetu Łódzkiego, Łódź. 